\title{
Salmonella spp. in the fish production chain: a review
}

\author{
Dandara Virginia Guia Semedo Fernandes ${ }^{1}$ Vinicius Silva Castro ${ }^{1,2}$ C \\ Adelino da Cunha Neto $^{3}$ Eduardo Eustáquio de Souza Figueiredo ${ }^{1,3,4^{*}}$
}

${ }^{1}$ Programa de Pós-graduação em Ciência Animal, Universidade Federal de Mato Grosso (UFMT), Cuiabá, MT, Brasil.

${ }^{2}$ Programa de Pós-graduação em Ciência de Alimentos, Universidade Federal do Rio de Janeiro (UFRJ), Rio de Janeiro, RJ, Brasil.

${ }^{3}$ Faculdade de Nutrição, Universidade Federal do Mato Grosso (UFMT), Cuiabá, MT, Brasil.

${ }^{4}$ Programa de Pós-graduação em Nutrição, Alimentos e Metabolismo, Laboratório de Microbiologia Molecular de Alimentos, Faculdade de Nutrição, Universidade Federal do Mato Grosso (UFMT), 78060-900, Cuiabá, MT, Brasil. E-mail: figueiredoeduardo@ufmt.br. "Corresponding author.

ABSTRACT: Salmonella spp is a pathogen responsible for severe foodborne infections, can be introduced into the fish production chain through inadequate handling or hygiene or contact with contaminated water, and is not a biological contaminant originally reported in fish. Fish microbiological safety is a concern for consumers, industries and regulatory agencies worldwide, since fish, an important food category in the international trade and often exported to several countries, can act as a vehicle for Salmonella transmission throughout the production chain. In addition, concerns regarding the misuse of antibiotics in aquaculture are also an issue, as a result of the increased isolation of resistant and multiresistant Salmonella serovars. In this review, we examined aspects associated with the microbiological risks of the presence of Salmonella spp. in fish and their implication in the aquaculture production chain. In addition, incidence and antimicrobial resistance data are presented, as well as strategies for Salmonella prevention and control in fish.

Key words: aquaculture, enterobacteriacae, antibiotic, antimicrobial resistance, salmonellosis.

\section{Salmonella spp. na cadeia produtiva do peixe: uma revisão}

RESUMO: Salmonella spp. é um patógeno responsável por uma grave infecção alimentar que pode ser introduzida na cadeia do pescado, por meio da manipulação e higiene inadequada ou por contato do peixe com águas contaminadas. Essa bactéria não é contaminante natural no pescado. Por isso, a segurança microbiológica do pescado é uma preocupação dos consumidores, indústrias e das agências reguladoras em todo mundo, uma vez que o pescado é importante produto para comércio internacional de alimentos, sendo frequentemente exportados para vários países podendo ser veículador da transmissão de Salmonella em toda a cadeia produtiva. Outro aspecto preocupante é quanto ao uso inadequado de antibióticos na aquicultura, o que vem resultando no aumento do isolamento de sorovares de Salmonella resistentes e multidroga resistentes. Nesta revisão, são examinados aspectos associados ao risco microbiológico da presença de Salmonella spp. no pescado e sua implicação na cadeia produtiva da aquicultura. Dados sobre a incidência e resistência antimicrobiana e estratégias de prevenção e controle de Salmonella no pescado no Brasil e no mundo são apresentados e discutidos.

Palavras-chave: aquacultura, enterobacteriacae, antibióticos, resistência antimicrobiana, salmonelose.

\section{INTRODUCTION}

Fish are seen as a substitute for beef, pork and poultry, since consumers now demand meat containing less fat, to meet a modern and healthy lifestyle (CBI, 2016). Thus, the agricultural outlook of the UN Food and Agriculture Organization (FAO) for fish production is the production of 195 million tonnes by 2025, while consumption is expected to reach $21.8 \mathrm{~kg}$ per capita per year, on all continents (GLOBEFISH HIGHLIGHTS, 2016).

To meet the growing demands for fish, safety is an important factor to consider, since these animals may be vehicles for the transmission of certain pathogens, such as Salmonella. In fact, the
European Food Safety Authority reported that food products that most caused foodborne in Europe in 2016 were chicken $(9 \%)$, cheese $(8 \%)$ and fish (7\%). Salmonella was responsible for $7.5 \%$ of cases associated with outbreaks in Brazil in 2016, while this bacterium caused 7,728 cases of foodborne in 2015 in the United States, representing a $15.89 \%$ incidence (CDC, 2016). In Europe, a total of 4,362 food-borne outbreaks were reported, most of them caused by bacterial agents, in particular Salmonella spp., which accounted for $21.8 \%$ of all outbreaks in 2015 (EFSA, 2016).

Salmonella is not a biological contaminant originally reported in fish, being introduced through contaminated waterorimproperhandling(SANT'ANA, 
2012). The fact that this bacterium survives in soil and water and may be transfered to fish plays an important role in providing information on the nature of the contamination and the possible dissemination route of this bacterium, thus allowing traceability of the microbial source in fish slaughterhouses (SETTI et al., 2009; HOFFMANN et al., 2016).

In this context, a literature review was carried out on Salmonella in fish and its implications in the production chain of aquaculture fish, in order to better understand the contamination dynamics with the aim of proposing preventive actions.

\section{Salmonella}

Salmonella belongs to the Enterobacteriaceae family, characterized as a nonsporulated gram-negative bacillus. It is routinely classified by serotype, based on the expression of three types of antigens: (O) somatic, $(\mathrm{H})$ flagellar and (vi) capsular, according to the Kauffmann-White scheme (BRASIL, 2011). This current classification scheme is based on two main Salmonella species: $S$. enterica and $S$. bongori. In this scheme, $S$. enterica is further classified into 6 sub-species: $S$. enterica subspecie enterica (I); S. enterica subspecie salamae (II); S. enterica subspecie arizonae (IIIa); S. enterica subspecie diarizonae (IIIb); S. enterica subspecie houtenae (IV) and $S$. enterica subspecie indica (V). Currently more than 2,600 serovars have been identified, including 1,547 belonging to $S$. enterica enterica (DEKKER \& FRANK, 2015), which causes $99 \%$ of diseases in humans and animals (GRIMONT \& WEILL, 2007; CDC, 2008; ISSENHUTHJEANJEAN et al., 2014).

The $S$. enterica subsp. enterica serovar Typhimurium and Enteritidis are the most common and can cause diseases in several animals (THOMSON et al., 2008; EFSA/ECDPC, 2017). Some serogroups are adapted to specific species. For example, $S$. enterica Typhi and S. enterica Paratyphi are restricted to humans, causing typhoid and paratyphoid fever, respectively (HOLT et al., 2009). Those adapted to cattle, $S$. enterica Dublin, and to pigs, $S$. enterica Choleraesuis, are occasionally reported in humans, causing severe ailments (SIRICHOTE et al., 2010; GAL-MOR, BOYLE \& GRASSL, 2014).

Salmonella is a facultative anaerobic, and oxidase-negative, usually mobile, that produces gas from glucose. Its growth temperature ranges from $7^{\circ} \mathrm{C}$ to $46^{\circ} \mathrm{C}$, with temperature optimum ranging from $35^{\circ} \mathrm{C}$ to $43^{\circ} \mathrm{C}$ and, growth $\mathrm{pH}$ ranging from 3.8 to 9.5 , with optimum $\mathrm{pH}$ between 7.0 and 7.5. Minimum water activity for growth is 0.84 and optimum salt concentration is up to 4\% (JARVIS et al., 2016). Regarding biochemical identification, Salmonella is catalase and methyl red positive, and indole, vogues proskauer, malonate and urea negative. It produces hydrogen sulphide gas $\left(\mathrm{H}_{2} \mathrm{~S}\right)$ from the reduction of sulfur through cysteine desulphydrase and displays as metabolic characteristics decarboxylation capacity regarding the amino acids lysine and ornithine, nitrate to nitrite reduction and the use of citrate as the only carbon of (BRASIL, 2011).

\section{Pathogenicity mechanisms}

In humans, salmonellosis causes gastroenteritis, bacteremia and more serious systemic diseases, such as typhoid and typhoid fever (BIBI et al., 2015). Infection mechanism by Salmonella spp. in humans institutes several steps along the gastrointestinal tract for the infection to be able to occur in the host. However, the bacteria must invade multiple gut defenses until gaining access to the epithelium. Salmonella spp. presents an adaptive tolerance response to acidic environments, such as the stomach, that allow for its survival under these conditions. When arriving in the intestinal mucosa, it adheres to the epithelium by means of fimbriae, which facilitate attachment to the intestinal epithelium (Figure 1) (MADIGAN et al., 2010; MONACK, 2012; THOMPSON et al., 2017).

The $\mathrm{M}$ cells and enterocytes are the main access ports to the pathogen. From M cells, a transcytosis process occurs, and Salmonella reaches the submucosa, where it comes into contact with phagocytes and activates virulence mechanisms, allowing its survival and replication in phagocytes (OLIVEIRA et al., 2013; WOTZKA et al., 2017).

SopE, SopE2 and SopB proteins act together to trigger changes in the cytoskeleton of host actin cells. Since Salmonella crosses the epithelial lining, secretion of type III protein (T3SS-2) allows the pathogen to survive in mononuclear tissues, such as macrophages and dendritic cells (THIENNIMITR et al., 2012; WOTZKA et al., 2017).

Endocrine Salmonella then resides and proliferates within a modified vacuole. These vacuoles perform transcytosis to the basolateral membrane. Simultaneously, the induction of a secretory response in the intestinal epithelium leads to phagocyte recruitment and transmigration from the submucosa to the intestinal lumen (Figure 1).

Subsequently, intestinal epithelium is reconstituted. After passing through the epithelium, the bacterium is engulfed by phagocytes, especially macrophages. Thus, the SipB protein is secreted, 


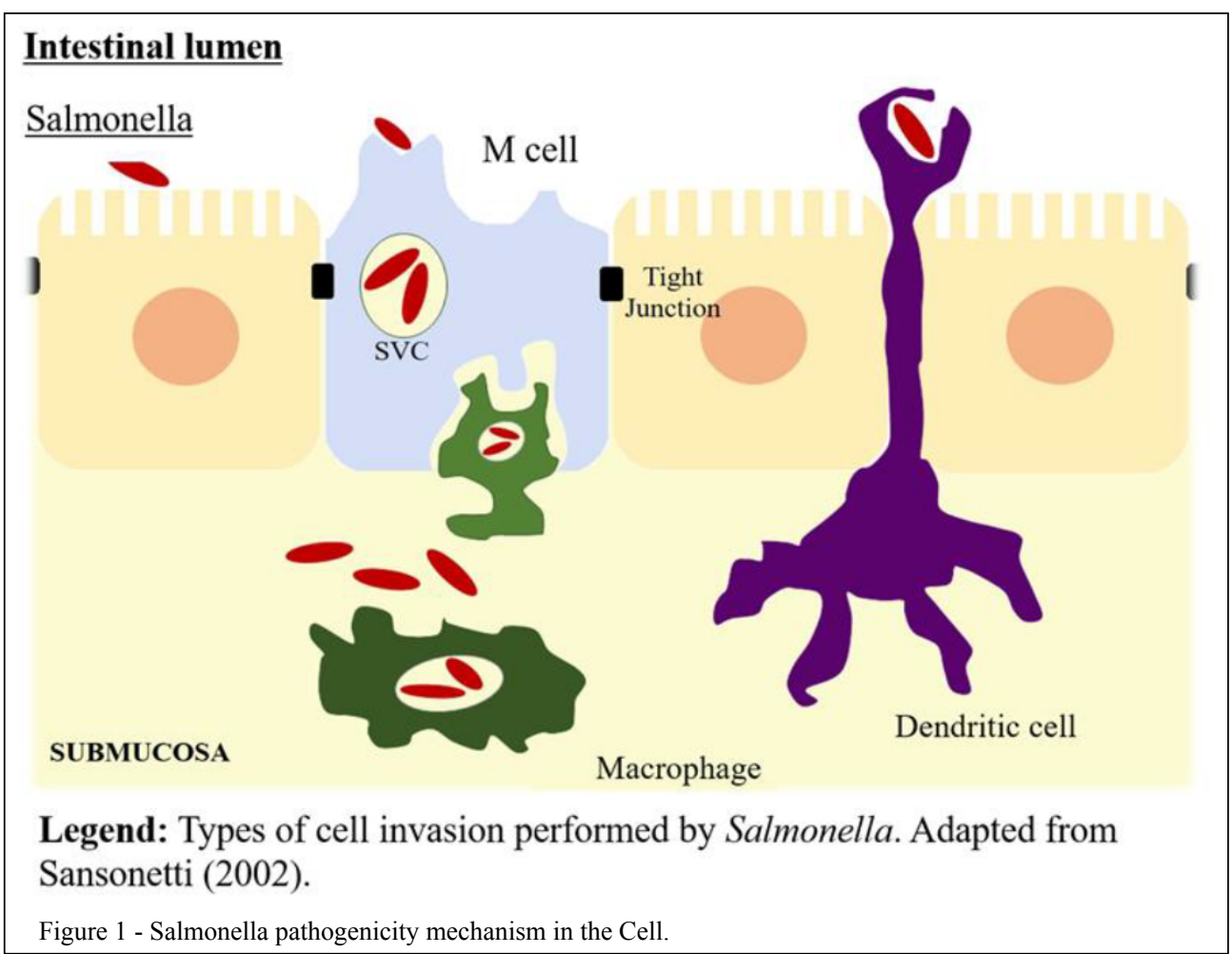

inducing macrophage death through a pyroptose process (FORTES et al., 2012).

Salmonella pathogenesis in fish is unknown. However, SANTOS (2015) developed an experimental infection protocol for some species, such as tambaqui (Colossoma macropomum), piau (Leporinus friderici), pintado (Pseudoplatystoma corruscans), and concluded that Salmonella can remain in the gastrointestinal tract in fish in a transient manner. In addition, the presence of the bacterium was detected in the fish feces. Consequently, this is an important factor for environmental contamination and bacterial spread.

\section{Salmonella in aquaculture}

The microbiota of recently captured fish reflects that of the water they inhabited, and the more polluted the water, the more varied the microbiota (VASEMÄGI et al., 2017) Therefore, environmental factos such as water quality play a significant role in the incidence of Salmonella in fish and a great risk for those consuming fish caught in contaminated waters without sanitary control (SANTIAGO et al., 2013; MATACA, 2014).

Several factors influence the risk of microbiological contamination in aquaculture products, mainly location, cultivated species, breeding practices, processing and cultural habits. Some of these potential microbiological hazards may be associated with poor hygiene patterns and sewage and livestock drainage. Leaching, for example, carries environmental pollutants into river waters and; consequently, fish, causing deleterious effects in this system (SETTI et al., 2009; TRAORÉ et al., 2015).

Another factor contributing to Salmonella contamination in fish is the use of poultry litter as fertilizer in culture tanks (ESPOSTO et al., 2007; AMPOFO \& CLERK, 2010), as well as rearing in consortium with other types of animals, such as poultry, cattle and pigs (LI et al., 2017), which contributes to the increase of the microbial population in fish tanks. Consequently, fish may undergo physiological changes due to direct access of contaminants to the bloodstream through gills (MOUNTAIN et al., 2011; GOSSNER et al., 2015).

Fish stress factors, such as incorrect management practices, unbalanced diets or tank overcrowding, can increase susceptibility to diseases and facilitate the spread of pathogens by decreasing immune responses, thus altering fish efficiency in combating infectious agents (AMAGLIANI \& SCHIAVANO, 2012). Once contaminated, fish may 
become Salmonella hosts and present no clinical manifestations (BIBI et al., 2015). Some studies have demonstrated the high incidence of Salmonella in fish intestines, skin and gills (NWIYI \& ONYEABOR, 2012), as well as muscle (EL-OLEMY et al., 2014). Salmonella presence on fish surface and internal organs facilitates cross-contamination during fish processing (HEINITZ et al., 2000).

\section{Cross contamination and prevalence in fish}

Salmonella is not a normal bacterial component of fish microbial flora, and the occurrence of this pathogen is commonly related to its breeding, as well as to the industrialization environment, due to inefficient hygiene practices, equipment and inadequate food handling. Therefore, fish slaughterhouses must take special care in the handling, storage, preservation, transport and commercialization of these animals, since the quality of the final product depends on these factors (FREITAS \& LOURENÇO, 2012).

Fish contamination in slaughterhouses can occur during all processing stages, such as transportation, washing with hyperchlorinated water, evisceration, peeling, and filleting, as well as contact with ice used for conservation, contaminated water, boards, knives, trays and plastic boxes (Figure 2).

Thus, adequate sanitary conditions during processing, including handler hygiene, as well as that of the surfaces used for fish manipulation, such as tables and utensils, in addition to the use of clean and chlorinated water during all processing steps, are essential to avoid cross contamination (DUARTE et al., 2010).

One of the most important factors regarding Salmonella cross-contamination is the fact that this bacterium can remain viable on food contact surfaces for significant periods. This is due to the formation of biofilms, a well-known bacterial mode of survival that protects bacteria from stressful environmental conditions, such as drying and cleaning procedures (CARRASCO et al., 2012). Cross-contamination associated with raw and processed food through contact surfaces is considered a potentially dangerous event, and some authors have reported the presence of Salmonella on stainless steel surfaces (WANG et al., 2015).

Contamination also occurs due to the inadequate sanitary status of food handlers who have salmonellosis and who become carriers during a certain

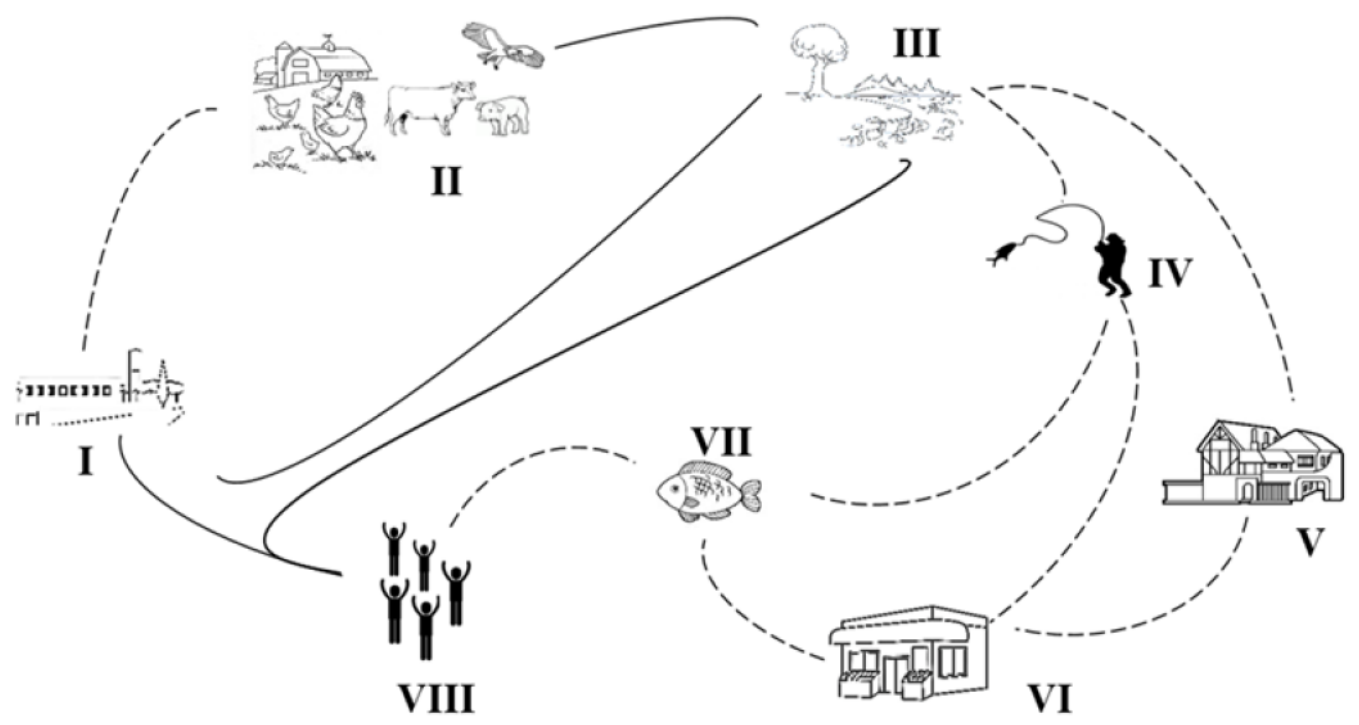

Legend: I - treatment of effluents and sewage; II - irrigation in agricultural production; III waste leaching and disposal; IV - extractive fishing; V - fish slaughterhouses; VI - fish marketing; VII - fish (extractive activities or fish farming); VIII - population. Dotted lines: Indirect Salmonella contamination sources. Continuous lines: Direct Salmonella contamination sources

Figure 2 - Contamination cycle by Salmonella in fish production activities. 
period after the disease symptoms have subsided. These carriers excrete Salmonella bacteria in faeces and, because of insufficient personal hygiene, create public health risks, since they may cause fish contamination when handling food during the unloading, processing or preparation steps (MATACA, 2014).

Control strategies to prevent fish-associated diseases include the identification and implementation of hygienic-sanitary controls during processing (AMAGLIANI \& SCHIAVANO, 2012). In the industrial environment, the most commonly applied program to guarantee food quality is the HACCP-based system (Hazard Analysis and Critical Control Points), which establishes control measures at pre-established points in the processing line and $\mathrm{CP}$ (control point) and/or CCP (critical control point) monitoring, as well as management practices focused on record-keeping and corrective actions (CORNIER et al., 2007).

The incidence of salmonellosis due to fish consumption has become a concern for public health agencies in several countries, due to the significant increase in consumption of aquaculture produces, especially raw products, which increase pathogen exposure risks, especially in vulnerable groups, such as elderly, pregnant women and infants (ZHANG et al., 2015; PAUDYAL et al., 2017).

The importance of this pathogen in fish can be assessed and evaluated, since records indicated that fish were responsible for the occurrence of $7 \%$ of total foodborne outbreaks in Europe in 2016, with the majority of Salmonella infections in humans related to fish consumption caused by the Typhimurium and Enteritidis serovars (SANTIAGO et al., 2013; EFSA, 2016).

In the United States, this bacterium was responsible for 20,000 admissions and 380 deaths per year over a three-year period (BAE et al., 2015). In 2015, also in the US, a Salmonella outbreak was identified, with the recall of frozen raw tuna (Thunnus alalunga) from an Indonesian industry. This led to 65 people becoming infected with Salmonella Paratyphi B and Salmonella Weltevreden in 11 American states (CDC, 2015).

Another study, conducted on 11,3120 seafood samples imported from different countries over a 9-year period in which they were collected by the Food and Drug Administration (FDA) concluded that the overall incidence of Salmonella spp. in seafood was of $7.2 \%$, and that incidence rates are higher in Central Pacific and African countries, or developing countries, compared to developed countries, such as countries in Europe, including Russia, and North America, that displayed a significantly lower incidence. (HEINITZ et al., 2000).

In general, the Typhimurium and Enteritidis serotypes are the most prevalent in developed countries; although, other serotypes predominate in specific regions, such as the Stanley and Weltevreden serotypes in Asia (Table 1). These differences can be justified due to differences in the way animals are raised and the large trade flow between different countries (SANTOS, 2015).

Studies have pointed to a $10.4 \%(19 / 384)$ prevalence of Salmonella in fresh fish in Iran, where five different serotypes were detected, namely $S$. Typhimirium, S. Enteretidis, S. Typhi, S. Paratyphi B and $S$. Newport (RAHIMI et al., 2013).

In Brazil, few studies on Salmonella in fish are available. However, in the northeastern region of the country, a $5 \%$ occurrence of this bacterium in fish and captive crustaceans has been reported (DUARTE et al., 2010), as well as $18.5 \%$ in salted and dried shrimp and fish meal, respectively, marketed in retail markets of the city of Belém, in the state of Pará (SILVA \& FRANCO, 2013), and 3.4\% contamination incidence in Nile tilapia (Oreochromis niloticus) was also reported in the same state (ESPOSTO et al., 2007).

\section{Microbiological standards for fish processing and marketing}

Each fish-importing country establishes its own microbiological and physico-chemical standards, while each importing company also has its evaluation criteria, usually of a confidential nature. In Brazil, before being commercialized, the fish are inspected by the Ministry of Agriculture, Livestock and Supply (MAPA). When leaving the industry, the inspection responsibility passes to the Ministry of Health and in the different states, the responsibility is transferred to the respective state health departments through the sanitary surveillance system. All food control and inspection involve its own legislation, laws, decrees, resolutions, ordinances and technical standards (FARIAS \& FREITAS, 2008).

In Brazil, Resolution RDC No. 12 of January 2, 2001 by the National Agency of Sanitary Surveillance - ANVISA (BRASIL, 2001), defines the microbiological criteria for foods exposed for sale and export. In item 7 of Annex I, the resolution addresses the maximum levels for microorganisms in "chilledor frozen fish, not consumed raw". The criterion of absence of Salmonella in foods complies with World Health Organization (WHO) recommendations.

Fish are passive Salmonella transporters that can excrete the bacteria without apparent symptoms or clinical manifestations. In these cases, when there is no efficient sanitary barrier, such as washing with hyperchlorinated water and quality control programs (GMP, HACCP, PPHO), Salmonella 
Table 1 - Salmonella prevalence in fish products.

\begin{tabular}{|c|c|c|c|c|c|c|}
\hline Fish & Reared/Captured & $\begin{array}{c}\text { Prevalence } \\
\%\end{array}$ & Source & $\begin{array}{l}\text { Samples } \\
\text { (Positive) }\end{array}$ & $\begin{array}{l}\text { Implicated } \\
\text { serovars }\end{array}$ & Reference \\
\hline $\begin{array}{l}\text { Shrimp (P. monodon) } \\
\text { Freshwater fish }\end{array}$ & Reared & $\begin{array}{l}49.1 \% \\
36.6 \%\end{array}$ & Vietnam & $409(84)$ & $\begin{array}{l}S . \text { Typhimurium } \\
S . \text { Anatum } \\
S . \text { Weltevreden }\end{array}$ & Nguyen et al., (2016) \\
\hline $\begin{array}{l}\text { Mussels (Mytilus spp.) } \\
\text { Fish } \\
\text { Shrimp (Penaeus spp.) } \\
\text { Shellfish }\end{array}$ & Reared & $\begin{array}{c}27.2 \% \\
12.4 \% \\
4.6 \% \\
6.0 \%\end{array}$ & China & $730(217)$ & $\begin{array}{l}\text { S. Aberdeen; } \\
\text { S. Stanley; } \\
\text { S. Wandsworth } \\
\text { S. Typhimurium }\end{array}$ & Zhang et al., (2015) \\
\hline $\begin{array}{l}\text { Seafood [Octopus } \\
\text { (Octopus spp.);Blu(e } \\
\text { anchovy } \\
\text { (Pomatomus salratrix) } \\
\text { Freshwaters Fihes [Tilapia } \\
\text { (Tilapia rendalli)] }\end{array}$ & Reared/Captured & $\begin{array}{l}44.5 \% \\
17.3 \%\end{array}$ & $\begin{array}{l}\text { United } \\
\text { States }\end{array}$ & $3840(110)$ & $\begin{array}{l}S . \text { Weltevreden } \\
\text { S. Newport } \\
\text { S. Senftenberg }\end{array}$ & Bae et al., (2015) \\
\hline $\begin{array}{l}\text { Pangas (Pangasianodon } \\
\text { hypophthalmus) } \\
\text { Catfish (Clarias } \\
\text { gariepinus) } \\
\text { Tilapia (Tilapia } \\
\text { mossambica) } \\
\text { Rohu (Labeorohita spp.) }\end{array}$ & Reared & $\begin{array}{c}60 \% \\
35 \% \\
64 \% \\
26.6 \%\end{array}$ & $\begin{array}{l}\text { Saudi } \\
\text { Arabia }\end{array}$ & $223(89)$ & - & Elhadi (2014) \\
\hline Catfish (Clarias spp.) & Reared & $11.5 \%$ & Nigeria & $200(23)$ & $\begin{array}{l}\text { S. Hadar } \\
\text { S. Eko }\end{array}$ & Raufu et al., (2014) \\
\hline $\begin{array}{l}\text { Shrimp (P. brasiliensis) } \\
\text { Nile Tilapia (Oreochromis } \\
\text { niloticus) } \\
\text { Lobster tail (Palinurus } \\
\text { spp.) }\end{array}$ & Reared & $\begin{array}{l}2.8 \% \\
4.0 \% \\
4.5 \%\end{array}$ & Brazil & $143(5)$ & - & Duarte et al., (2010) \\
\hline $\begin{array}{l}\text { Mussels (Mytilus spp.) } \\
\text { Seawater sample } \\
\text { Marine sediment }\end{array}$ & Captured & $\begin{array}{l}10 \% \\
4.1 \% \\
6.8 \%\end{array}$ & Morroco & $801(57)$ & $\begin{array}{l}S . \text { Blockley } \\
S . \text { Kentucky } \\
S . \text { Senftenberg }\end{array}$ & Setti et al., (2009) \\
\hline $\begin{array}{l}\text { Silver carp } \\
\text { (Hypophthalmichthys } \\
\text { molitrix) }\end{array}$ & Reared & $2.7 \%$ & Iran & $39(1)$ & - & Basti et al., (2006) \\
\hline $\begin{array}{l}\text { Nile Tilapia (Oreochromis } \\
\text { niloticus) }\end{array}$ & Reared & $3.4 \%$ & Brazil & $116(4)$ & - & Esposto et al., (2007) \\
\hline $\begin{array}{l}\text { Mussels (Mytilus spp.) } \\
\text { Oysters (Ostrea edulis) }\end{array}$ & Captured & $\begin{array}{l}3.1 \% \\
2.5 \%\end{array}$ & Spain & $5,384(127)$ & $\begin{array}{c}S . \text { Senftenberg } \\
S . \text { Typhimurium } \\
\text { S. Agona }\end{array}$ & Martinez et al.,(2004) \\
\hline
\end{tabular}

dissemination throughout the processing stages will occur (BUDIATI et al., 2013; BIBI et al., 2015).

Washing with hyperchlorinated water occurs during the first stage of fish processing, recommended at $5 \mathrm{ppm}$ of free residual chlorine (BRASIL, 2009). This step aims at eliminating bacteria from the breeding environment and the mucus present on fish surfaces, which consists of glycoproteins released by the skin glands and is a culture medium for the proliferation of undesirable microorganisms. The wash water should be at a low temperature, so as not to allow digestive enzymes to act before evisceration. Thus, at this stage, exposure time and chlorine concentrations should be adequate 
to eliminate pathogens present on fish surfaces (MACHADO et al., 2010).

Salmonella and Listeria have been reported to be more resistant to chlorine inactivation than Escherichia strains in a system consisting of washing fresh products with hyperchlorinated water. Thus, for inactivation of Salmonella in Panga fish (Pangasius hypophthalmus), a chlorine concentration of 10ppm was used for at least 30 seconds. Although, washing with hyperchlorinated water is often a control point, a critical control limit has not been validated (ZHOU et al., 2015; THI et al., 2016).

The presence of Salmonella in the evisceration and descaling stages occurs due to operational failures, mainly due to viscera rupture, that exposes the meat to the bacterial contamination of gut contents, mainly of intestine, contaminating the handler's hands and disseminating the bacteria to other fishes. Considering that Salmonella may be present in the gastrointestinal tract, this is undoubtedly an important cross-contamination factor in fish slaughterhouses. In order to control crosscontamination, washing the intestinal cavity and the surface of the fish with hyperchlorinated water after the evisceration stage, should be performed, in order to eliminate blood and gut remains (MATACA, 2014; SANTOS, 2015).

Another important step is commercialization, since poor fish conservation is often observed at marketing points, due to the inadequate use of chilling and infrastructure, as well as inefficient services. Detection of this pathogen indicates that the current Salmonella control strategies in fish production, processing and commercialization steps are not fully effective (AMAGLIANI \& SCHIAVANO 2012). Thus, control should be based on the identification of CCPs throughout the fish production chain, in order to prevent fish contamination by Salmonella and other pathogens.

\section{Salmonella antimicrobial resistance}

A self-limiting gastroenteritis is the main clinical picture developed by Salmonella, which in severe cases may require replacement of liquid and electrolytes. The use of antibiotics is reserved for patients with serious diseases or at high risk of invasive diseases (WHO, 2014). Antibiotic therapy scheme for typhoid fever includes the third generation cephalosporin antibiotics, quinolones and macrolides. However, lately has been growing between typhoid Salmonellas and non-typhoid strains with high levels of resistance to quinolones and cephalosporin (COSBY et al., 2015). Emergence of multiple drug resistant to Salmonella (MDR) is currently a worldwide concern, and the occurrence of Salmonella MDR in food is a risky condition, representing an increase in the severity of Foodborne Disease, leading to increased hospitalization rates and possibility of death (CRUMP et al., 2015). Conversely, the epidemiology of antimicrobial resistance of Salmonella spp. Is complex and may be influenced by factors such as: antibiotic consumption, human travel, transmission between patients in hospitals, importation and trade of food of animal origin or not, trade in live animals in the country or between countries and exposure through an animal or human environment (ECDC/EFSA/EMA, 2017).

\section{Salmonella resistant to antibiotics isolated from fish}

Contribution of aquaculture to the global supply of fish, crustaceans, molluscs and other aquatic animals has increased considerably over the past four decades, also becoming a risk factor for consumers, due to the widespread and inappropriate use of antimicrobial drugs in aquaculture and risks associated with the spread of resistance between pathogens to humans (AMAGLIANI \& SCHIAVANO 2012).

Antibiotic residues in food can generate allergies and toxicity that are difficult to diagnose, due to the lack of knowledge on the source of their intake, which can cause exposure in subinhibitory concentrations and lead to the appearance of resistance in both commensal bacteria of the human intestine and fish bacteria, with possible dissemination of resistance genes to various bacterial populations (GASTALHO et al., 2014).

In Morocco, 28 (49.1\%) Salmonella isolates showed resistance to ampicillin (22 isolates), nalidixic acid (9 isolates), sulfonamide compounds (2 isolates) and tetracycline (1 isolates). Six isolates showed resistance to two antimicrobial substances (SETTI et al., 2009).

In a study carried out by EHADI et al. (2014), a total of 140 Salmonella isolates from six different types of frozen freshwater fish: catfish (Clarias gariepinus), carfu (Corfu toothcarp), mrigal (Cirrhinus cirrhosus), tilapia (Oreochromis mossambicus), rohu (Labeo rohita) were detected in samples imported from five different countries (Thailand, Vietnam, Bahrain, Myanmar and India). Isolates were tested for susceptibility to 18 selected antimicrobial agents, with most isolates showing resistance to tetracycline (90.7\%) followed by ampicillin (70\%) and amoxicillin and clavulanic acid $(45 \%)$.

In Nigeria, RAUFU et al. (2014) isolated 23 Salmonella strains from African catfish 
(Clarias gariepinus), with the two most frequent serovars identified as $S$. Hadar and $S$. Eko. Overall antimicrobial resistance patterns indicated that most isolates were resistant to streptomycin 10 (43.5\%), sulfamethoxazole $8(34.8 \%)$ and trimethoprim 5 (21.7\%), which constitutes a serious health risk for humans. MARTINEZ-URTAZA and LIEBANA (2005) characterized a total of 106 S. Senftenberg isolates from 8 Spanish mussel processing plants (from both mussels and environmental samples) that displayed antimicrobial resistance to 16 antibiotics. The authors reported 9 strains resistant to one or more antibiotics, including apramycin, chloramphenicol, nalidixic acid, neomycin, streptomycin, sulfamethoxazole-trimethoprim, sulfonamide, tetracycline and amoxycillin acid.

YANG et al. (2015) evaluated the antimicrobial resistance profile of 554 samples, of which 86 were positive for Salmonella. The highest contamination rates were observed in oysters (23\%), freshwater fish (18\%) and shrimp (13\%). S. Typhimurium and S. Wandsworth were the most prevalent. Isolates were tested for 19 antimicrobials and showed resistance to tetracycline $(35.9 \%)$, ampicillin (28.2\%), nalidixic acid (26.2\%), trimethoprimsulfamethoxazole $(25.2 \%)$, chloramphenicol $4 \%$ ) and streptomycin (18.4\%).

In Brazil, few studies have characterized the occurrence of bacterial resistance in aquaculture environments, particularly in freshwater fish. CARVALHO et al. (2009) isolated 103 Salmonella strains in shrimp water samples and reported that serovars $S$. Newport, Panama and Saintpaul were the most prevalent. Isolates were submitted to antibiograms with 10 antimicrobials and $4 \%$ of the strains showed resistance to tetracline, $2 \%$ to nalidixic acid and $2 \%$ to sulfamethoxazole. This indicated the risks from antibiotic use by crustacean farmers and that their discharge in rivers near commercial points presents a risk for the selection of antimicrobialresistant bacteria.

In a study conducted by COSTA et al. (2016), the antimicrobial susceptibility of 21 Salmonella strains obtained from Tilapia (Oreochromis spp.), both whole and in fillets, in the state of São Paulo was determined. Isolates were sensitive to gentamicin (95\%), amikacin $(66 \%)$ and ciprofloxacine $(66 \%)$, and resistant to florfenicol (80\%), which is surprising, since its use is relatively recent in veterinary medicine in Brazil.

These reports confirmed the occurrence of microbial resistance in several environments, including aquaculture activities, evidencing transfer risks of resistant bacteria to humans through the consumption of aquaculture products or by indirect genetic transfer (NGUYEN et al., 2016).

A potential issue that has increased recently is the worldwide appearance of multidrug resistant phenotypes among Salmonella serotypes, such as $S$. Typhimurium and $S$. Enteritidis, especially resistance to quinolones, fluoroquinolones or cephalosporin.

\section{CONCLUSION}

Although, Salmonella is not part of natural fish microbiota, fish can become asymptomatic hosts, housing the bacteria mainly on the body surface and intestines, causing cross contamination in the industrialization and commercialization stages. The water quality and the aquaculture environment have a direct influence on microbiological fish contamination.

Most salmonellosis cases related to fish consumption in humans are caused by serovars $S$. Typhimurium and $S$. Enteritidis. The prevalence of Salmonella in freshwater fish ranges between 3.4 and $64 \%$, related to water quality and good manufacturing practices (GMP).

During fish processing, the washing step with hyperchlorinated water should always be considered a CCP, since no further processing step can eliminate Salmonella. In this sense, the biggest challenge is to establish the best combination of chlorine exposure time vs. concentration required to inactivate the pathogen. Salmonella antibiotic-resistant strains have been isolated in fish in Brazil and worldwide, which evidences the transference of resistance genes among the aquatic microbial population, which can lead to more severe and difficult to treat foodborne infections.

\section{ACKNOWLEDGEMENTS}

The Coordenação de Aperfeiçoamento de Pessoal Docente, Brazil (CAPES) by fellowship.

\section{CONFLICTS OF INTEREST}

The authors declare no conflict of interest. The founding sponsors had no role in the design of the study; in the collection, analyses, or interpretation of data; in the writing of the manuscript, and in the decision to publish the results.

\section{REFERENCES}

AMAGLIANI, G. B. G.; G. F. SCHIAVANO. Incidence and role of Salmonella in seafood safety. Food Research International. 45(2):780-788. 2012. Available from: <https://www.sciencedirect. com/science/article/pii/S0963996911004005?via\%3Dihub>. Accessed: Feb. 18, 2018. doi: 10.1016/j.foodres.2011.06.022. 
AMPOFO, J. A.; CLERK. G. C. Diversity of bacteria contaminants in tissues of fish cultured in organic waste-fertilized ponds: health implications. Open Fish Science Journal. 3:142-146. 2010. Available from: <https://benthamopen.com/ ABSTRACT/TOFISHSJ-3-142>. Accessed: Feb. 18, 2018. doi: 10.2174/1874401X01003010142.

BAE, D. et al. Characterization of extended-spectrum $\beta$-lactamase (ESBL) producing non-typhoidal Salmonella (NTS) from imported food products. International Journal of Food Microbiology. 214:12-17. 2015. Available from: $<$ https://www.sciencedirect.com/ science/article/pii/S0168160515300702?via\%3Dihub>. Accessed: Feb. 18, 2018. doi: 10.1016/j.ijfoodmicro.2015.07.017.

BASTI, A. A. et al. Bacterial pathogens in fresh, smoked and salted Iranian fish. Food control 17:183-188. 2006. Available from: <https://www.sciencedirect.com/science/ article/pii/S0956713504002312?via\%3Dihub>. Accessed: Feb. 18, 2018. doi: 10.1016/j.foodcont.2004.10.001.

BIBI, F. et al. Occurrence of Salmonella in freshwater fishes: A review. Journal of Animal and Plant Sciences. 25:303310. 2015. Available from: <https://pdfs.semanticscholar. org/046a/133ec70484cbec13f1c7868debb86efadd5e.pdf $>$. Accessed: Feb. 18, 2018.

BRASIL. Ministério da Agricultura, Pecuária e Abastecimento. 2009. Ofício Circular GAB/DIPOA ${ }^{\circ}$ 25/2009, de 13 de novembro de 2009. Departamento de Inspeção de Produtos de Origem Animal - DIPOA. Procedimentos de Verificação dos Programas de Autocontrole em Estabelecimentos de Pescado e Derivados. Brasília - DF.

BRASIL. Ministério da Saúde. Secretaria de Vigilância em Saúde. 2011. Manual técnico de diagnóstico laboratorial de Salmonella spp.: diagnóstico laboratorial do gênero Salmonella / Ministério da Saúde. Secretaria de Vigilância em Saúde, Fundação Oswaldo Cruz. Laboratório de Referência Nacional de Enteroinfecções Bacterianas, Instituto Adolfo Lutz. - Brasília. Available from: <http:// portalarquivos2.saude.gov.br/images/pdf/2014/dezembro/15/manualdiagnostico-salmonella-spp-web.pdf $>$. Accessed: Feb. 18, 2018.

BRASIL. Agência Nacional de Vigilância Sanitária (ANVISA). 2001. n ${ }^{\circ} 12$, de 02 de janeiro de 2001. Dispõe sobre os princípios gerais para o estabelecimento de critérios e padrões microbiológicos para alimentos. Brasília - DF. Available from: $<\mathrm{http}$ ://portal.anvisa. gov.br/documents/33880/2568070/RDC_12_2001.pdf/15ffddf63767-4527-bfac-740a0400829b>. Accessed: Feb. 18, 2018.

BUDIATI, T. et al. Prevalence, antibiotic resistance and plasmid profiling of Salmonella in catfish (Clarias gariepinus) and tilapia (Tilapia mossambica) obtained from wet markets and ponds in Malaysia. Aquaculture. 372:127-132. 2013. Available from: <https://www.sciencedirect.com/science/ article/pii/S004484861200659X?via\%3Dihub>. Accessed: Feb. 18, 2018. doi: 10.1016/j.aquaculture.2012.11.003.

BUJJAMMA, P. et al. Incidence of Salmonella species in fish and shellfish of Guntur domestic fish market, Andhra Pradesh, India. International Journal of Current Research Academic Review. 3:177-185. 2015. Available from: <http://www.ijcrar.com/vol-35/P.\%20Bujjamma,\%20et\%20al.pdf>. Accessed: Feb. 18, 2018.

CARRASCO, E. et al. Cross-contamination and recontamination by Salmonella in foods: a review. Food Research International, 45:545-556. 2012. Available from: <https://www.sciencedirect.
com/science/article/pii/S0963996911006260?via\%3Dihub>. Acessed: Feb. 18, 2018. doi: 10.1016/j.foodres.2011.11.004.

CARVALHO, F. C. T. et al. Antimicrobial susceptibility of Salmonella spp. isolated from carcass farms in the State of Ceará. Revista Ciência Agronômica, 40:549-556. 2009. Available from: <http://ccarevista.ufc.br/seer/index.php/ccarevista/article/ view/891>. Accessed: Feb. 18, 2018.

CDC. Center Diseases Control. 2008. Salmonella surveillance: annual summary, 2006. US Department of Health and Human Services, Atlanta. Available from: <https://www.cdc.gov/ncezid/ dfwed/PDFs/salmonella-annual-summary-2007-508c.pdf $>$. Accessed: Feb. 18, 2018.

CDC. Center Diseases Control. 2015. Multistare Outbreak of Salmonella Parathyphi B variant L and tartrate and Salmonella Weltevreden infections linked to frozen raw tuna. Available from: $<$ https://www.cdc.gov/Salmonella/paratyphi-b-05-15/index. html>. Accessed: Nov. 27, 2017.

CDC. Center Diseases Control. 2016. Foodborne Diseases. Available from: <https://www.cdc.gov/mmwr/volumes/65/wr/mm6514a2.htm>. Accessed: Jul. 29, 2017.

COSBY, D. E. et al. Salmonella and antimicrobial resistance in broilers: A review. J.Appl. Poult. Res. 24:408-426. 2015. Available from: <https://academic.oup.com/japr/article/24/3/408/758013>. Accessed: Jul. 29, 2017. doi: 10.3382/japr/pfv038.

COSTA, T. D. et al. Qualidade microbiológica de tilápias obtidas de pesqueiros no interior do estado de São Paulo, Brasil. Ciência \& Tecnologia, 8. 2016. Available from: <http://www.citec.fatecjab.edu. br/index.php/files/article/viewFile/705/pdf $>$. Accessed: Jul. 29, 2017.

CRUMP, J. A.; Heyderman, R. S. A Perspective on Invasive Salmonella Disease in Africa. Clinical Infectious Diseases 61(S4):S235-40, 2015. Available from: <https://academic.oup. com/cid/article/61/suppl 4/S235/458434>. Accessed: Feb. 18, 2018. doi: $10.1093 / \mathrm{cid} / \mathrm{civ} 709$.

DEKKER, J. P.; FRANK, K. M. Salmonella, Shigella, and yersinia. Clinics in laboratory medicine, 35:225-246. 2015. Available from: <https://www.ncbi.nlm.nih.gov/pmc/articles/PMC4443274/>. Accessed: Jul. 29, 2017.

DUARTE, D. A. M. ett al. Ocorrência de Salmonella spp. e Staphylococcus coagulase positiva em pescado no Nordeste, Brasil. Arquivo do Instituto Biológico, 77:711-713. 2010. Available from: <http://www.biologico.sp.gov.br/uploads/docs/ arq/v77_4/duarte.pdf $>$. Accessed: Jul. 29, 2017.

ELHADI, N. Prevalence and antimicrobial resistance of Salmonella spp. in raw retail frozen imported freshwater fish to Eastern Province of Saudi Arabia. Asian Pacific Journal of Tropical Biomedicine, 4:234-238 2014. Available from: <https://www.sciencedirect.com/ science/article/pii/S2221169115301982?via\%3Dihub>. Accessed: Jul. 29, 2017. doi: 10.1016/S2221-1691(14)60237-9.

EL-OLEMY, G. M. et al. Detection of some bacterial zoonosis in market fish in Qalyoubia province and their control. Benha Veterinary Medical Journal, 2:5. 2014.

ESPOSTO, E. M. et al. Bacterial enteropathogens from fishes of a nutrient recycle system and its ecosystem. Pesquisa Veterinária Brasileira, 27:144-148 2007. Available from: 
$<$ http://www.scielo.br/scielo.php?script=sci_arttext\&pid=S0100736X2007000400003>. Accessed: Jul. 29, 2017.

EFSA. European Food Safety Autority. 2016. Guidelines for reporting data on zoonoses, antimicrobial resistance and foodborne outbreaks using the EFSA data models for the data collection framework (DCF) to be used in 2017 for 2016 data, ISSN 2397-8325. Available from: $<$ http://onlinelibrary.wiley.com/ doi/10.2903/sp.efsa.2017.EN-1178/pdf>. Accessed: Feb. 05, 2017.

ECDC (European Centre for Disease Prevention and Control), EFSA (European Food Safety Authority), and EMA (European Medicines Agency), 2017. ECDC/EFSA/EMA second joint report on the integrated analysis of the consumption of antimicrobial agents and occurrence of antimicrobial resistance in bacteria from humans and food-producing animals - Joint Interagency Antimicrobial Consumption and Resistance Analysis (JIACRA) Report. EFSA Journal 15(7):4872, 2017. 135 pp. Available from: <https:// efsa.onlinelibrary.wiley.com/doi/full/10.2903/j.efsa.2017.4872>. Accessed: Jan. 22, 2018. doi:10.2903/j.efsa.2017.4872.

FAO. Food and Agriculture Organization of the United Nations. 2016. The State of World Fisheries and Aquaculture 2016. Contributing to food security and nutrition for all. Rome. 200 pp. Available from: <http://www.fao.org/3/a-i5555e.pdf > Accessed: Jan. 22, 2018

FARIAS, M. D. C. A.; FREITAS, J. D. A. Qualidade microbiológica de pescado beneficiado em indústrias paraenses. Revista do Instituto Adolfo Lutz, 67:113-117. 2008.

FORTES, T. P. et al. Ilhas de patogenicidade de Salmonella enterica: uma revisão. Revista do Instituto Adolfo Lutz, 71:219227. 2012. Available from: <http://www.ial.sp.gov.br/resources/ insituto-adolfo-lutz/publicacoes/rial/rial71 2 completa/1458. pdf $>$. Accessed: Jan. 22, 2018.

FREITAS, J. D. A.; LOURENÇO, L. D. F. H. Avaliação dos perigos microbiológicos em uma indústria de beneficiamento de pescados e sugestão de um sistema de gestão de qualidade. Tese de doutorado. Universidade Federal da Paraíba. 2012. Available from: $<$ http://repositorio.ufpa.br/jspui/handle/2011/4674>. Accessed: Jan. 22,2018 .

GAL-MOR, O. et al. Same species, different diseases: how and why typhoidal and non-typhoidal Salmonella enterica serovars differ. Frontiers in Microbiology, 5(391):1-10, 2014. Available from: $<$ https://www.frontiersin.org/articles/10.3389/fmicb.2014.00391/ full>. Accessed: Jan. 22, 2018. doi: 10.3389/fmicb.2014.00391.

GASTALHO, S. et al. Uso de antibióticos em aquacultura e resistência bacteriana: impacto em saúde pública. Acta Farmacêutica Portuguesa, 3:29-45. 2014. Available from: $<$ http://actafarmaceuticaportuguesa.com/index.php/afp/article/ view/40>. Accessed: Jan. 22, 2018

GLOBEFISH HIGHLIGHTS. A quarterly update on worl seafood markerts Jan- Mar 2016 Statiscs. FAO. GLOBEFISH Highlights 4:62. 2016. Available from: <http://www.fao.org/3/ai6094e.pdf $>$. Accessed: Jan. 22, 2018.

GOSSNER C. M. et al. Event-based surveillance of food- and waterborne diseases in Europe: 'urgent inquiries' (outbreak alerts) during 2008 to 2013. Euro Surveill. 20(25): pii=21166, 2015. Available from: <http://www.eurosurveillance.org/ViewArticle. aspx?ArticleId=21166>. Accessed: Jan. 22, 2018.
GRIMONT P. A. D.; WEILL, F. X. Antigenic formulae of the Salmonella serovars, 9th edn. WHO Collaborating Center for Reference and Research on Salmonella. 2007. Institut Pasteur Paris, France.

HEINITZ, M. L. et al. Incidence of Salmonella in fish and seafood. Journal of Food Protection, 63:579-592. 2000. Available form: $<$ https://www.ncbi.nlm.nih.gov/pubmed/10826714>. Accessed: Jan. $22,2018$.

HOFFMANN, M. et al. Tracing Origins of the Salmonella Bareilly Strain Causing a Food-borne Outbreak in the United States. The Journal of Infectious Diseases, 213:502-8. 2016. Available from: $<$ https://academic.oup.com/jid/article/213/4/502/2459204>. Accessed: Jan. 22, 2018.

HOLT, K. E. et al. Pseudogene accumulation in the evolutionary histories of Salmonella enterica serovars Paratyphi A and Typhi. BMC Genomics, 10:36. 2009. Available from: <https://bmcgenomics. biomedcentral.com/articles/10.1186/1471-2164-10-36>. Accessed: Jan. 22, 2018

ISSENHUTH-JEANJEAN, S. et al. Supplement 2008e2010 (no. 48) to the WhiteeKauffmanneLe Minor scheme. Research in Microbiology, 165: 526-530, 2014. Available from: <https:// linkinghub.elsevier.com/retrieve/pii/S0923250814001065>. Accessed: Jan. 22, 2018.

JARVIS, N. A. et al. An overview of Salmonella thermal destruction during food processing and preparation. Food Control, 68:280-290. 2016. Available from: <https:/www.sciencedirect. com/science/article/pii/S095671351630175X?via\%3Dihub>. Accessed: Jan. 22, 2018.

LI, K., G. et al. Salmonella Weltevreden in integrated and nonintegrated tilapia aquaculture systems in Guangdong, China. Food Microbiology, 65:19-24. 2017. doi: 10.1016/j.fm.2017.01.014.

MACHADO, T. R. M. et al. Avaliação da resistência de Salmonella à ação de desinfetantes ácido peracético, quaternário de amônio e hipoclorito de sódio. Revista do Instituto Adolfo Lutz, 69:475481. 2010.

MADIGAN, M. et al. Microbiologia De Brock. 12a edição. 2010. editora Artmed. Porto Alegre.

MARTINEZ-URTAZA, J.; LIEBANA. E. Use of pulsed-field gel electrophoresis to characterize the genetic diversity and clonal persistence of Salmonella senftenberg in mussel processing facilities. International Journal of Food Microbiology, 105:153-163. 2005. Available from: $<$ https://www.sciencedirect.com/science/article/pii/ S0168160505003211?via\%3Dihub>. Accessed: Jan. 22, 2018

MONACK, D. M. Salmonella persistence and transmission strategies. Current Opinion in Microbiology, 15:100-107. 2012. doi: 10.1016/j.mib.2011.10.013>. Accessed: Jan. 22, 2018.

NGUYEN, D. T. A. et al. Prevalence, antibiotic resistance, and extended-spectrum and AmpC $\beta$-lactamase productivity of Salmonella isolates from raw meat and seafood samples in Ho Chi Minh City, Vietnam. International Journal of Food Microbiology, 236:115-122. 2016. doi: 10.1016/j.ijfoodmicro.2016.07.017. Accessed: Jan. 22, 2018.

NWIYI, P., ONYEABOR, A. Occurrence of Salmonella spp. from fresh fish (Tilapia nilotica Linn) using improved isolation methods. 
Online Journal of Animal and Feed Research, 2:475-478. 2012. Available from: <http://www.thejaps.org.pk/docs/Supplementary/ v-25-sup-2/03.pdf $>$. Accessed: Jan. 22, 2018.

OLIVEIRA, A. P., et al. Salmonella enterica: genes de virulência e ilhas de patogenicidade. Enciclopédia Biosfera, 3:12. 2013 Available from: <http://www.conhecer.org.br/enciclop/2013a/ agrarias/salmonella.pdf $>$. Accessed: Jan. 22, 2018.

PAUDYAL, N. V. et al. Prevalence of foodborne pathogens in food from selected African countries-A meta-analysis. International Journal of Food Microbiology, 249:35-43. 2017. doi: 10.1016/j. ijfoodmicro.2017.03.002.

RAHIMI, E. et al. Prevalence and antimicrobial resistance of Salmonella isolated from fish, shrimp, lobster, and crab in Iran. Comparative Clinical Pathology, 22:59-62. 2013. Available from: $<$ https://link.springer.com/article/10.1007/s00580-011-1368-3>. Access: Jan. 22, 2018.

RAUFU, I. A.; et al. Occurrence and antimicrobial susceptibility profiles of Salmonella serovars from fish in Maiduguri, subSaharah, Nigeria. The Egyptian Journal of Aquatic Research, 40:59-63. 2014. Available from: <https://www.sciencedirect.com/ science/article/pii/S1687428514000053?via\%3Dihub>. Accessed: Jan. 22, 2018 .

SANT'ANA, A. Introduction to the Special Issue: Salmonella in foods: evolution, strategies and challenges. Food Research International 45:451-454. 2012. Available from: $<$ https://www.sciencedirect.com/ science/article/pii/S0963996912000294?via\%3Dihub>. Accessed: Jul. 29, 2017.

SANTIAGO, J. D. A. S. et al. Bactérias patogênicas relacionadas à ingestão de pescados-revisão. Arquivos de Ciências do Mar, 46:2. 2013. Available from: <http://www.periodicos.ufc.br/ arquivosdecienciadomar/article/view/908>. Accessed: Jan. 22, 2018

SANTOS, R. R. D. Ocorrência, tipagem molecular e capacidade de colonização de amostras de Salmonella enterica em peixes nativos. Tese de doutorado. Universidade Federal de Minas Gerais. 2015. Available from: <http://www.bibliotecadigital.ufmg.br/dspace/ handle/1843/SMOC-A7LHUD>. Accessed: Jan. 22, 2018

SETTI, I., A. et al. Characteristics and dynamics of Salmonella contamination along the coast of Agadir, Morocco. Applied and Environmental Microbiology, 75:7700-7709. 2009. Available from: $<$ http://aem.asm.org/content/75/24/7700.full $>$. Accessed: Jan. 22, 2018.

SILVA, M. C. et al. Avaliação da qualidade do camarão salgado seco (aviú) e da farinha de peixe (piracuí) comercializados em mercados varejistas da cidade de Belém, Pará. Revista do Instituto Adolfo Lutz, 72:147-54. 2013. Available from: <http://pesquisa.bvsalud. org/portal/resource/pt/vti-12296>. Accessed: Jan. 22, 2018.

SIRICHOTE, P. et al. Molecular characterization of extendedspectrum cephalosporinase-producing Salmonella enterica serovar Choleraesuis isolates from patients in Thailand and Denmark. Journal Clinical Microbiology, 48:883-888. 2010. Available from: <https://www. ncbi.nlm.nih.gov/pubmed/20032253>. Accessed: Jan. 22, 2018.

THI, A. N. T., et al. Evaluation of the safety and quality of wash water during the batch washing of Pangasius fish (Pangasius hypophthalmus) in chlorinated and non-chlorinated water LWT-Food Science and Technology, 68:425-431. 2016.
Available from: <https://www.sciencedirect.com/science/ article/pii/S0023643815304059?via\%3Dihub>. Accessed: Jan. $22,2018$.

THIENNIMITR, P. et al. Salmonella, the host and its microbiota. Current Opinion in Microbiology, 15:108-114. 2012. Available from: $<$ https://www.sciencedirect.com/science/ article/pii/S136952741100172X?via\%3Dihub>. Accessed: Jan. $22,2018$.

THOMPSON, C.K. et al. Epidemiology and whole genome sequencing of an ongoing point-source Salmonella Agona outbreak associated with sushi consumption in western Sydney, Australia 2015. Epidemiol. Infect., 1-10. 2017. Available from: <https:// www.cambridge.org/core/journals/epidemiology-and-infection/ article/epidemiology-and-whole-genome-sequencing-of-anongoing-pointsource-salmonella-agona-outbreak-associated-withsushi-consumption-in-western-sydney-australia-2015/703D7CB6 DB78FC104F52C1436822BE4F>. Accessed: Jan. 22, 2018.

TRAORÉ, O., et al. Prevalence and diversity of Salmonella enterica in water, fish and lettuce in Ouagadougou, Burkina Faso. BMC Microbiology, 15:151. 2015. Available from: <https:// bmcmicrobiol.biomedcentral.com/articles/10.1186/s12866-0150484-7>. Accessed: Jan. 22, 2018.

VASEMÄGI, A. et al. Effect of Environmental Factors and an Emerging Parasitic Disease on Gut Microbiome of Wild Salmonid Fish. of wild salmonid fish. MSphere 2(6):e00418-17. 2017. doi: 10.1128/mSphere.00418-17

WANG, H. et al. Comparison of microbial transfer rates from Salmonella spp. biofilm growth on stainless steel to selected processed and raw meat. Food Control, 50:574-580. 2015. Available from: <https://www.sciencedirect.com/science/article/ pii/S0956713514005702?via\%3Dihub>. Accessed: Jan. 22, 2018.

WHO, World Health Organization. Antimicrobial resistance: global report on surveillance. 2014, Publications of the World Health Organization are available on the WHO website (www. who.int) or can be purchased from WHO Press, World Health Organization, 20 Avenue Appia, 1211 Geneva 27, Switzerland. Available from: <www.who.int/about/licensing/copyright_form/ en/index.html>. Accessed: Jan. 22, 2018.

WOTZKA, S, Y. et al. Salmonella Typhimurium Diarrhea Reveals Basic Principles of Enteropathogen Infection and DiseasePromoted DNA Exchange. Cell Host \& Microbe 21(12):443-454, 2017. doi: 10.1016/j.chom.2017.03.009.

YANG, X., et al. Prevalence, enumeration, and characterization of Salmonella isolated from aquatic food products from retail markets in China. Food Control, 57:308313. 2015. Available from: <https://www.sciencedirect.com/ science/article/pii/S0956713515002224?via\%3Dihub>. Accessed: Jan. 22, 2018.

ZHANG, J., et al. Prevalence of antimicrobial resistance of nontyphoidal Salmonella serovars in retail aquaculture products. International Journal of Food Microbiology, 210:47-52. 2015. doi: $0.1016 /$ j.ijfoodmicro.2015.04.019.

ZHOU, B. et al. Inactivation dynamics of Salmonella enterica, Listeria monocytogenes, and Escherichia coli O157: $\mathrm{H} 7$ in wash water during simulated chlorine depletion and replenishment processes. Food Microbiology, 50:88-9. 2015. doi: 10.1016/j.fm.2015.03.004. 